\title{
PENGARUH KADAR ACCELERATOR TERHADAP KUAT TEKAN PADA HIGH STRENGTH SELF COMPACTING CONCRETE (HSSCC) BENDA UJI SILINDER UMUR 3, 7, 14, DAN 28 HARI
}

\author{
Wibowo'), Endah Safitri2), Wahyu Hapsari3) \\ 1) Pengajar Prodi Teknik Sipil, Fakultas Teknik, Universitas Sebelas Maret \\ 2) Pengajar Prodi Teknik Sipil, Fakultas Teknik, Universitas Sebelas Maret \\ 3) Mahasiswa Fakultas Teknik, Prodi Teknik Sipil, Universitas Sebelas Maret \\ Jl. Ir. Sutami 36A, Surakarta 57126; Telp. 0271-634524. \\ Email: wahyuhapsari.11a5.29@gmail.com
}

\begin{abstract}
Along with the times. construction progress is increasing, One of the main materials used in the construction is concrete, Therefore. the need for concrete is getting higher, Other than. addition for concrete is getting higher. addition for high strength concrete is also getting higher. Because of this. needed innovations in concrete, One of the concrete innovations that can be done is to make high strength concrete that can compact itself (High Strength Self Compacting Concrete - HSSCC). with compressive strength above 41.4 MPa, In this research. innovation was carried out by using admixtures that is superplasticizer and accelerator, Superplasticizer is added to achieve bigh workability, While the accelerator is to speed up the binding process and develop the initial strength of concrete, Accelerator is also used to shorten the setting time so that it accelerates the achievement of concrete strength, The superplasticizer content used was $0.8 \%$. and the accelerator content variation was $0 \% .0 .4 \% .1 .2 \%$. and $2 \%$ of the weight of cement,

The research was carried out in stages starting from aggregate test. SCC test. and concrete compressive strength test, SCC test was carried out with 3 methods. that is flow table test to determine fillingability parameters. l-box test to determine passingability parameters. and v-funnel test to determine fillingability and segregation resistance, The specimens used are cylindrical with a diameter of $7.5 \mathrm{~cm}$ and height of $15 \mathrm{~cm}$. where the sample will be tested with a compressive strength test using Universal Testing Machine (UTM) at the ages of 3. 7. 14. and 28 days,

Based on the results of the SCC test on fresh concrete. the replacement of cement with accelerator content of $0.4 \%$ gives good results because it is able to meet all SCC parameters with EFNARC standards, Based on the results of testing the compressive strength of concrete using superplasticizer $0.8 \%$ and variations in the addition of accelerator showed that the higher the addition of accelerator content and the longer the lifespan of the concrete, the compressive strength of the concrete is getting bigher, The maximum percentage of accelerator content that can be used to achieve High Strength Self Compacting Concrete (HSSCC) is 0.4\%, With a compressive strength value of 43.09 MPa. it meets the minimum standards of high strength compressive concrete required by SNI-03-6468-2000,
\end{abstract}

Keywords: Accelerator. High Strength Self Compacting Concrete. Compressive strength. SCC. Superplasticizer.

\begin{abstract}
ABSTRAK
Seiring dengan berkembangnya zaman, perkembangan konstruksi semakin lama semakin meningkat. Salah satu bahan utama yang digunakan dalam konstruksi adalah beton. Oleh karena itu, kebutuhan terhadap beton semakin tinggi. Selain permintaan terhadap beton semakin tinggi, permintaan terhadap beton mutu tinggi juga semakin tinggi. Oleh sebab itu, diperlukan inovasi-inovasi pada beton. Salah satu inovasi beton yang dapat dilakukan adalah dengan membuat beton mutu tinggi yang dapat memadat sendiri (High Strength Self Compaction Concrete - HSSCC), dengan kuat tekan diatas 41,4 MPa. Dalam penelitian ini, dilakukan inovasi dengan menggunakan bahan tambah berupa superplasticizer dan accelerator. Superplasticizer ditambahkan untuk mencapai workability yang tinggi. Sedangkan accelerator adalah untuk mempercepat proses pengikatan dan mengembangkan kekuatan awal beton. Accelerator juga digunakan untuk memperpendek waktu pengikatan semen sehingga mempecepat pencapaian kekuatan beton. Kadar superplasticizer yang digunakan adalah $0,8 \%$, dan variasi kadar accelerator sebesar $0 \%, 0,4 \%, 1,2 \%$, dan 2\% dari berat semen.

Penelitian dilakukan secara bertahap mulai dari pengujian agregat, pengujian SCC, dan pengujian kuat tekan beton. Pengujian SCC dilakukan dengan 3 metode, yaitu flow table untuk mengetahui parameter fillingability, l-box test untuk mengetahui parameter passingability, dan v-funnel test untuk mengetahui fillingability serta segregation resistance. Benda uji yang digunakan berbentuk silinder dengan diameter $7,5 \mathrm{~cm}$ dan tinggi $15 \mathrm{~cm}$, dimana benda uji ini diuji dengan uji kuat tekan menggunakan Universal Testing Machine (UTM) pada umur 3, 7, 14, dan 28 hari.

Berdasarkan hasil uji SCC pada beton segar, penggantian semen dengan kadar accelerator sebesar $0,4 \%$ memberikan hasil yang baik karena mampu memenuhi seluruh parameter SCC dengan standar EFNARC. Berdasarkan hasil pengujian kuat tekan beton yang menggunakan superplasticizer $0,8 \%$ dan variasi penambahan accelerator menunjukkan
\end{abstract}


bahwa semakin tinggi penambahan kadar accelerator dan semakin lama umur beton, maka kuat tekan beton yang dihasilkan semakin tinggi. Persentase maksimum kadar accelerator yang dapat digunakan agar dapat mencapai High Strength Self Compacting Concrete (HSSCC) adalah 0,4\%. Dengan nilai kuat tekan sebesar 43,09 MPa, memenuhi standar minimum kuat tekan beton mutu tinggi yang disyaratkan SNI-03-6468-2000.

Kata Kunci : $\quad$ Accelerator, High Strength Self Compacting Concrete, kuat tekan, SCC, superplasticizer.

\section{PENDAHULUAN}

Seiring dengan berkembangnya zaman, perkembangan konstruksi semakin lama semakin meningkat. Ditambah lagi belakangan ini pemerintah sedang melakukan penggalakkan berbagai pembangunan infrastruktur. Semua bangunan infrastruktur tersebut membutuhkan struktur bangunan yang kokoh dan mampu menopang beban dari bangunan tersebut supaya tidak terjadi keruntuhan bangunan. Salah satu bahan utama yang digunakan dalam pembangunan infrastruktur ini adalah beton. Hal inilah yang menyebabkan permintaan terhadap beton semakin meningkat dengan pesat. Sehingga diperlukan inovasi untuk mendapatkan beton dengan kualitas yang tinggi, harga lebih murah, mudah dalam pengerjaannya, umur lebih tahan lama, dan beton dapat memadat lebih cepat.

Dalam penelitian ini dilakukan inovasi dengan menggunakan bahan tambah berupa superplasticizer dan accelerator. Penggunaan superplasticizer pada campuran beton digunakan untuk mencapai workability yang tinggi sekaligus dapat menekan faktor air semen. Sedangkan accelerator digunakan untuk mempercepat proses pengikatan dan pengembangan kekuatan awal beton. Bahan ini juga digunakan untuk memperpendek waktu pengikatan semen sehingga mempecepat pencapaian kekuatan beton. Hasil dari penelitian ini adalah menganalisis kuat tekan beton pada setiap persentase bahan tambahan accelerator yang digunakan pada High Strength Self Compacting Concrete (HSSCC).

\section{LANDASAN TEORI}

Beton merupakan suatu bahan komposit (campuran) dari berbagai material, yang bahan utamanya terdiri dari campuran antara semen, agregat halus, agregat kasar, air, dan atau tanpa bahan tambahan lain dengan perbandingan tertentu. Karena beton merupakan komposit, maka kualitas beton sangat tergantung dari kualitas masing-masing material pembentuk (Tjokrodimulyo, 2007).

Menurut Tjaronge et.al (2006) dan Hartono, et.al (2007), Self Compacting Concrete (SCC) adalah suatu beton yang ketika masih berbentuk beton segar mampu mengalir melalui tulangan dan memenuhi seluruh ruang yang ada didalam cetakan secara padat tanpa ada bantuan pemadatan manual atau getaran mekanik.

Beton mutu tinggi merupakan suatu bahan yang dibuat dari campuran beton (semen, agregat, air) dan pengurangan semen dengan penambahan zat aditif sesuai dengan perbandingan sedemikian rupa sehingga bahan itu merupakan satu kesatuan yang dapat membentuk kekuatan beton yang lebih tinggi. Beton mutu tinggi (bigh strength concrete) yang tercantum dalam SNI 03-6468-2000 didefinisikan sebagai beton yang mempunyai kuat tekan yang disyaratkan lebih besar sama dengan 41,4 MPa.

Superplasticizer dapat memperbaiki workabilitas namun tidak terpengaruh besar dalam meningkatkan kuat tekan beton untuk faktor air semen yang diberikan. Kegunaan superplasticizer untuk beton mutu tinggi secara umum sangat berhubungan dengan pengurangan jumlah air dalam campuran beton. Pengurangan ini tergantung dari kandungan air yang digunakan, dosis dan tipe dari superplasticizer yang dipakai (Parrot, 1998).

Accelerator adalah bahan kimia untuk mempercepat proses ikatan dan pengerasan beton. Bahan ini digunakan jika penuangan adukan dilakukan di bawah permukaan air, atau pada struktur beton yang memerlukan pengerasan segera. Beberapa macam accelerator, yaitu Calsium Chlorida $\left(\mathrm{CaCl}_{2}\right)$, Aluminium Chlorida $\left(\mathrm{AlCl}_{2}\right)$, Natrium Sulfat $\left(\mathrm{NaSO}_{4}\right)$, dan Aluminium Sulfat $\left(\mathrm{AlSO}_{4}\right)$.

Kuat tekan beton adalah besarnya beban per satuan luas, yang menyebabkan benda uji beton hancur bila dibebani dengan gaya tekan tertentu, yang dihasilkan oleh mesin desak. (SK SNI M-14-1989-F). Rumus yang digunakan untuk mendapatkan nilai kuat tekan beton (beton silinder dengan ukuran d $15 \mathrm{~cm}$ x $30 \mathrm{~cm}$ ) berdasarkan SNI 1974: 2011 tentang Cara Uji Kuat Tekan Beton dengan Benda Uji Silinder, dapat dilihat pada persamaan 1.

$f^{\prime} c=\frac{P}{A}$

dengan: 
$f^{\prime} c \quad=$ Kuat tekan beton $(\mathrm{MPa})$

$P \quad=$ Gaya tekan $(\mathrm{N})$

$A \quad=$ Luas penampang benda uji $\left(\mathrm{mm}^{2}\right)$

Untuk variasi dimensi silinder beton digunakan faktor pengali untuk mengkonversikan variasi dimensi silinder beton ke dimensi normal beton untuk uji kuat tekan berdasarkan asumsi yang diambil dari gambar 12.18 Compressive strength of cylinders of different sizes, A.M. Neville, Properties of Concrete (1995) adalah sebagai berikut:

Tabel 1. Faktor Pengali Variasi Dimensi Silinder Beton

\begin{tabular}{cccc}
\hline \multicolumn{2}{c}{ Ukuran Silinder $(\mathbf{m m})$} & Kuat Tekan & Faktor \\
Diameter & Tinggi & $(\%)$ & Pengali \\
\hline 50 & 100 & 108 & 0,917 \\
\hline 75 & 150 & 106 & 0,943 \\
\hline 100 & 200 & 104 & 0,962 \\
\hline 150 & 300 & 100 & 1,000 \\
\hline 200 & 400 & 96 & 1,042 \\
\hline
\end{tabular}

Dari tabel 1. dapat diketahui faktor pengali dari masing-masing variasi ukuran silinder. Sehingga untuk mengetahui nilai kuat tekan beton yang sebenarnya dapat dilakukan dengan mengkonversikan tegangan beton dengan faktor pengali dari ukuran silinder yang digunakan.

\section{METODE}

Metode yang digunakan dalam penelitian ini menggunakan metode uji eksperimental, di mana kondisi dibuat dan diatur oleh peneliti dengan mengacu pada EFNARC serta literatur yang berkaitan. Penelitian dilakukan secara bertahap mulai dari pengujian agregat, pengujian SCC, dan pengujian kuat tekan beton. Benda uji yang digunakan berbentuk silinder dengan diameter 7,5 cm dan tinggi $15 \mathrm{~cm}$, dimana benda uji ini akan diuji dengan uji kuat tekan menggunakan Universal Testing Machine (UTM) pada umur 3, 7, 14, dan 28 hari. Kadar superplasticizer yang digunakan adalah $0,8 \%$ dengan melakukan beberapa kali trial sedangkan untuk variasi kadar accelerator yang digunakan adalah $0 \%, 0,4 \%, 1,2 \%$, dan $2 \%$ dari berat semen yang digunakan dengan masing-masing sample berjumlah 3 buah per kadar superplasticizer dan accelerator.

Tabel 2. Jumlah dan Kode Benda Uji

\begin{tabular}{|c|c|c|c|c|c|c|c|}
\hline \multirow[t]{2}{*}{ No } & \multirow{2}{*}{$\begin{array}{c}\text { Kadar } \\
\text { Superplasti- } \\
\text { cizer }\end{array}$} & \multirow{2}{*}{$\begin{array}{c}\text { Kadar } \\
\text { Accelerator }\end{array}$} & \multirow{2}{*}{$\begin{array}{c}\text { Kode } \\
\text { Benda Uji } \\
\text { ACC }\end{array}$} & \multicolumn{4}{|c|}{ Jumlah Benda Uji } \\
\hline & & & & $\begin{array}{c}\text { (umur } 3 \\
\text { hari) }\end{array}$ & $\begin{array}{c}\text { (umur } 7 \\
\text { hari) }\end{array}$ & $\begin{array}{c}\text { (umur } 14 \\
\text { hari) }\end{array}$ & $\begin{array}{c}\text { (umur } 28 \\
\text { hari) }\end{array}$ \\
\hline 1. & $0,8 \%$ & $0 \quad \%$ & $0 \quad \%$ & 3 & 3 & 3 & 3 \\
\hline 2. & $0,8 \%$ & $0,4 \%$ & $0,4 \%$ & 3 & 3 & 3 & 3 \\
\hline 3. & $0,8 \%$ & $1,2 \%$ & $1,2 \%$ & 3 & 3 & 3 & 3 \\
\hline 4. & $0,8 \%$ & $2 \%$ & $2 \%$ & 3 & 3 & 3 & 3 \\
\hline \multicolumn{4}{|c|}{ Total Benda Uji } & \multicolumn{4}{|c|}{48} \\
\hline
\end{tabular}

Berdasarkan tabel 2. di atas maka dapat dilihat kode benda uji yang digunakan yaitu benda uji ACC 0\%, 0,4\%, $1,2 \%$, dan $2 \%$. Selain itu dari tabel di atas dapat diketahui juga jumlah benda uji dari masing-masing variasi kadar dan variasi umur benda uji. Dengan masing-masing variasi benda uji berjumlah 3 sampel dengan total benda uji adalah 48 sampel.
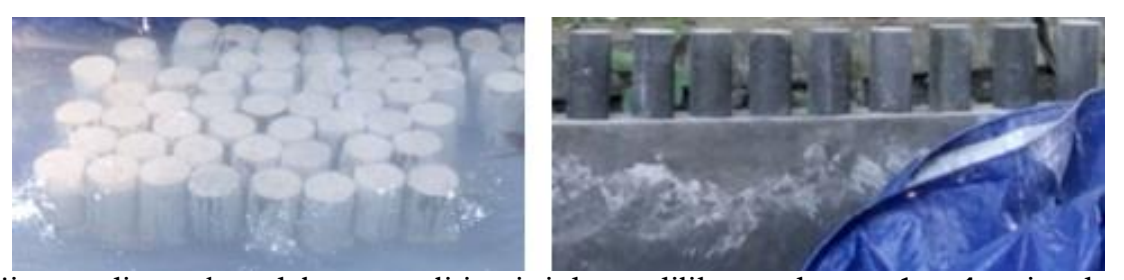

Perawatan benda uji yang diterapkan dalam penelitian ini dapat dilihat pada gambar 1. yaitu dengan cara curing dan

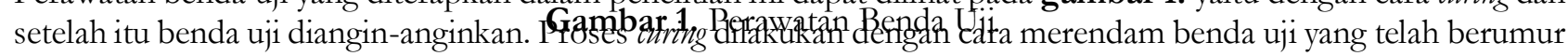
1 hari ke dalam bak curing. Kemudian dilakukan proses curing selama 1 hari untuk beton yang akan diuji diumur 3 hari, 3 hari untuk beton yang akan diuji diumur 7 hari, 7 hari untuk beton yang akan diuji diumur 14 hari, 21 hari 
untuk beton yang akan diuji diumur 28 hari. Setelah dilakukan proses curing beton dikeluarkan dari bak curing lalu diangin-anginkan sehingga didapatkan benda uji yang permukaannya kering.

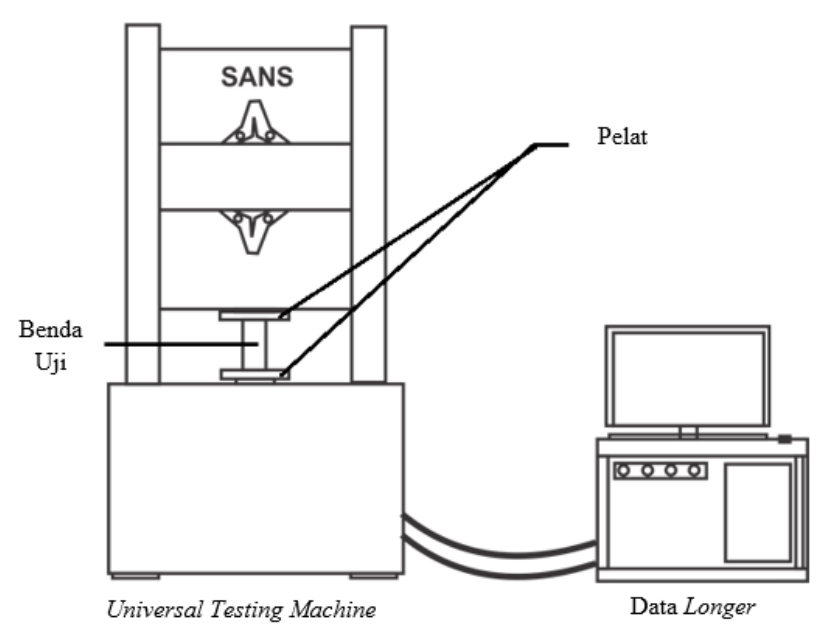

Gambar 2. Set Up Pengujian Kuat Tekan dengan Menggunakan UTM

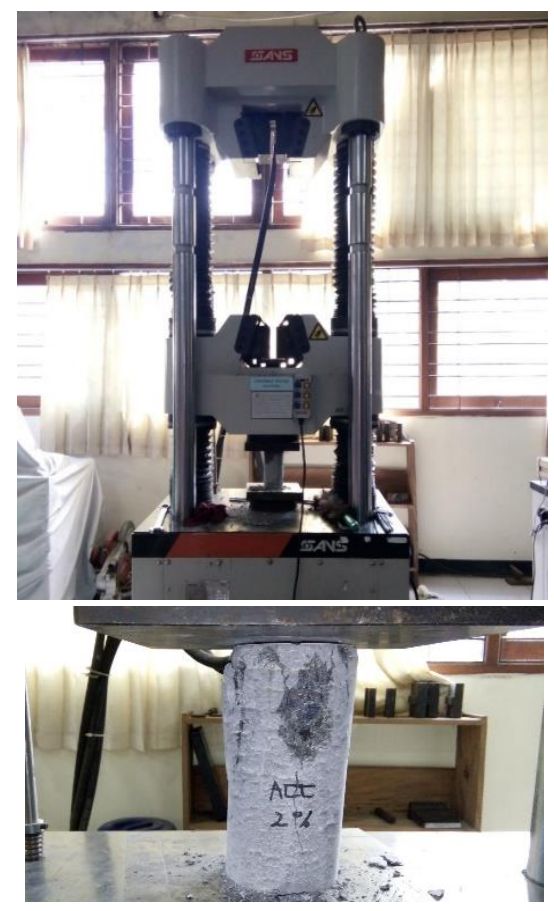

Gambar 3. Pengujian Kuat Tekan dengan Menggunakan UTM

Dari gambar 2. dapat dilihat set up pengujian kuat tekan dengan menggunakan UTM. Gambar tersebut menunjukkan posisi benda uji saat diletakkan pada mesin uji UTM. Sedangkan gambar 3. menunjukkan pengujian real di laboratorium mesin.

\section{ANALISIS DATA DAN PEMBAHASAN}

\section{Pengujian Agregat}

Pengujian agregat perlu dilakukan untuk mengetahui kualitas agregat yang akan digunakan dalam penelitian. Jika pengujian agregat telah memenuhi standar yang ada maka agregat dapat digunakan sebagai material penyusun beton.

Tabel 3. Rekapitulasi Hasil Pengujian Agregat Halus

\begin{tabular}{llll}
\hline \multicolumn{1}{c}{ Jenis Pengujian } & \multicolumn{1}{c}{ Hasil Pengujian } & \multicolumn{1}{c}{ Standar } & \multicolumn{1}{c}{ Keterangan } \\
\hline Bulk Spec Gravity SSD & $2,57 \mathrm{gr} / \mathrm{cm}^{3}$ & $2,5 \mathrm{gr} / \mathrm{cm}^{3}-2,7 \mathrm{gr} / \mathrm{cm}^{3}$ (ASTM) & Memenuhi syarat \\
\hline Kandungan Lumpur & $0,3 \%$ & $<5 \%(\mathrm{PBI} 1971)$ & Memenuhi syarat \\
\hline Kandungan Zat Organik & Kuning Muda & Kuning Muda (PBI 1971) & Memenuhi syarat \\
\hline Modulus Kehalusan & 2,59 & $1,5-3,8($ SII-0052-80) & Memenuhi syarat \\
\hline
\end{tabular}

Berdasarkan tabel 3. dapat disimpulkan bahwa agregat halus yang diuji memenuhi seluruh spesifikasi PBI 1971, SII-0052-80, dan American Standard Testing and Material (ASTM).

Tabel 4. Rekapitulasi Hasil Pengujian Agregat Kasar

\begin{tabular}{lcll}
\hline \multicolumn{1}{c}{ Jenis Pengujian } & Hasil Pengujian & \multicolumn{1}{c}{ Standar } & Keterangan \\
\hline Bulk. Spec Gravity SSD & $2,67 \mathrm{gr} / \mathrm{cm}^{3}$ & $2,5 \mathrm{gr} / \mathrm{cm}^{3}-2,7 \mathrm{gr} / \mathrm{cm}^{3}$ (ASTM) & Memenuhi syarat \\
\hline Abrasi & $19,73 \%$ & $<50 \%($ PBI 1971) & Memenuhi syarat \\
\hline Modulus Kehalusan & 7,37 & $5-8$ (SNI T-15-1990-03) & Memenuhi syarat \\
\hline
\end{tabular}

Dari tabel 4. dapat disimpulkan bahwa agregat kasar yang diuji memenuhi seluruh spesifikasi PBI 1971, SNI T15-1990-03, dan American Standard Testing and Material (ASTM). 
Perhitungan mix design mengacu pada EFNARC dan penelitian sebelumnya Fadillah, Yuda 2017. Pada penelitian ini menggunakan FAS 0,3 dengan superplasticizer BASF tipe 8851 sebanyak 0,8\% dari berat semen. Rekapitulasi mix design dapat dilihat pada tabel 5.

Tabel 5. Rekapitulasi Mix Design Beton per $1 \mathrm{~m}^{3}$

\begin{tabular}{|c|c|c|c|c|c|c|}
\hline $\begin{array}{l}\text { Kode BU } \\
\text { ACC }\end{array}$ & $\begin{array}{c}\text { Ag. Kasar } \\
\left(\mathrm{Kg} / \mathrm{m}^{3}\right)\end{array}$ & $\begin{array}{l}\text { Ag. Halus } \\
\left(\mathrm{Kg} / \mathrm{m}^{3}\right)\end{array}$ & $\begin{array}{l}\text { Semen } \\
\left(\mathrm{Kg} / \mathrm{m}^{3}\right)\end{array}$ & $\begin{array}{c}\text { Accelerator } \\
\left(1 \mathrm{l} / \mathrm{m}^{3}\right)\end{array}$ & $\begin{array}{c}\text { Air } \\
\left(1 t / \mathrm{m}^{3}\right)\end{array}$ & $\begin{array}{c}\text { Superplasticizer } \\
\left(1 \mathrm{lt} / \mathrm{m}^{3}\right)\end{array}$ \\
\hline$\%$ & 801,25 & 916,32 & 550 & 0 & 165 & 4,13 \\
\hline $0,4 \%$ & 801,25 & 916,32 & 547,26 & 1,71 & 164,18 & 4,11 \\
\hline $1,2 \%$ & 801,25 & 916,32 & 541,87 & 5,08 & 162,56 & 4,07 \\
\hline $2 \%$ & 801,25 & 916,32 & 536,58 & 8,38 & 160,98 & 4,03 \\
\hline
\end{tabular}

Berdasarkan tabel 5. dapat diketahui mix design beton untuk per $1 \mathrm{~m}^{3}$ nya. Untuk agregat kasar dan halus masingmasing benda uji per $1 \mathrm{~m}^{3}$ membutuhkan berat yang sama, yaitu $801,25 \mathrm{~kg}$ dan $916,32 \mathrm{~kg}$. Sedangkan untuk semen, accelerator, air, dan superplasticizer dibutuhkan berat per $1 \mathrm{~m}^{3}$ yang berbeda. Untuk kebutuhan semen pada benda uji $0 \%, 0,4 \%, 1,2 \%$, dan $2 \%$ per $1 \mathrm{~m}^{3}$ berturut-turut membutuhkan berat sebesar $550 \mathrm{~kg}, 547,26 \mathrm{~kg}, 541,87 \mathrm{~kg}, 536,58$ kg. Kebutuhan accelerator pada benda uji $\% \%, 0,4 \%, 1,2 \%$, dan $2 \%$ per $1 \mathrm{~m}^{3}$ berturut-turut membutuhkan volume sebesar 0 liter, 1,71 liter, 5,08 liter, 8,38 liter. Kebutuhan air pada benda uji $0 \%$, 0,4\%, 1,2\%, dan 2\% per $1 \mathrm{~m}^{3}$ berturut-turut membutuhkan volume sebesar 165 liter, 164,18 liter, 162,56 liter, 160,98 liter. Sedangkan untuk kebutuhan superplasticizer pada benda uji $0 \%, 0,4 \%, 1,2 \%$, dan $2 \%$ per $1 \mathrm{~m}^{3}$ berturut-turut membutuhkan volume sebesar 4,13 liter, 4,11 liter, 4,07 liter, 4,03 liter.

\section{Hasil Pengujian Parameter Beton SCC}

Pengujian parameter beton SCC dilakukan pada beton segar. Hal ini dilakukan untuk melihat konsentrasi campuran sebagai dasar untuk kemudahan pekerjaan. Pengujian parameter beton SCC yang dilakukan meliputi pengujian flow table, L-box, dan $V$-funnel.

Tabel 6. Rekapitulasi Hasil Pengujian Flow Table Test dan L-Box Test

\begin{tabular}{|c|c|c|c|c|c|c|c|c|}
\hline \multirow{3}{*}{$\begin{array}{c}\text { Kode BU } \\
\text { ACC }\end{array}$} & \multicolumn{5}{|c|}{ Flow Table Test } & \multicolumn{3}{|c|}{ L-Box Test } \\
\hline & $\begin{array}{l}\text { Diameter } \\
\text { Sebaran }\end{array}$ & $\begin{array}{c}\text { Syarat } \\
\text { EFNARC }\end{array}$ & $\mathbf{T}_{500}$ & $\begin{array}{c}\text { Syarat } \\
\text { EFNARC }\end{array}$ & Keterangan & $\mathbf{h}_{2} / \mathbf{h}_{1}$ & $\begin{array}{c}\text { Syarat } \\
\text { EFNARC }\end{array}$ & Keterangan \\
\hline & $(\mathrm{mm})$ & $(\mathrm{mm})$ & (s) & (s) & & & & \\
\hline $0 \%$ & 665 & \multirow{4}{*}{$650-800$} & 3.10 & \multirow{4}{*}{$2-5$} & Memenuhi & 1 & \multirow{4}{*}{$0.8-1.0$} & Memenuhi \\
\hline $0,4 \%$ & 670 & & 2.08 & & Memenuhi & 0.96 & & Memenuhi \\
\hline $1,2 \%$ & 655 & & 3.86 & & Memenuhi & 0.97 & & Memenuhi \\
\hline $2 \%$ & 650 & & 5.00 & & Memenuhi & 0.8 & & Memenuhi \\
\hline
\end{tabular}

Tabel 7. Rekapitulasi Hasil Pengujian V-funnel Test

\begin{tabular}{|c|c|c|c|c|c|c|}
\hline \multirow{3}{*}{$\begin{array}{c}\text { Kode BU } \\
\text { ACC }\end{array}$} & \multicolumn{6}{|c|}{ V-funnel Test } \\
\hline & $\mathbf{T}_{\text {awal }}$ & $\begin{array}{c}\text { Syarat } \\
\text { EFNARC }\end{array}$ & Keterangan & $\mathbf{T}_{5 \min }$ & $\begin{array}{c}\text { Syarat } \\
\text { EFNARC }\end{array}$ & Keterangan \\
\hline & (s) & (s) & & (s) & (s) & \\
\hline $0 \quad \%$ & 8.3 & \multirow{4}{*}{$8-12$} & Memenuhi & 12.2 & \multirow{4}{*}{$(+) 0-3$} & Memenuhi \\
\hline $0,4 \%$ & 12.04 & & Memenuhi & 20.93 & & Tidak Memenuhi \\
\hline $1,2 \%$ & 15.98 & & Tidak Memenuhi & 25.84 & & Tidak Memenuhi \\
\hline $2 \%$ & 21.89 & & Tidak Memenuhi & 43.51 & & Tidak Memenuhi \\
\hline
\end{tabular}

Dari rekapitulasi hasil pengujian parameter beton SCC yang terdapat pada tabel 6. dan tabel 7., dapat dilihat bahwa semakin tinggi kadar accelerator maka beton semakin tidak SCC. Diameter sebaran, perbandingan h2/h1 semakin kecil, selain itu Tawal dan T5min semakin besar. Hal ini menunjukkan bahwa setting time beton yang terjadi semakin cepat, sehingga menyebabkan beton semakin tidak dapat memenuhi parameter SCC. Untuk kadar accelerator sebesar 0,4\% memberikan hasil yang baik karena mampu memenuhi hampir seluruh parameter SCC dengan standar EFNARC.

\section{Hasil Pengujian Kuat Tekan Beton}


Pada penelitian ini, pengujian kuat tekan beton dilakukan pada umur 3 hari, 7 hari, 14 hari, dan 28 hari dengan menggunakan Universal Testing Machine (UTM) untuk mendapatkan beban maksimum yaitu beban yang mampu ditahan beton sampai beton mengalami retak atau hancur $\left(P_{\max }\right)$. Dari $P_{\max }$ tersebut akan diperoleh kuat tekan beton. Tetapi untuk beton silinder selain ukuran d $15 \mathrm{~cm}$ x $30 \mathrm{~cm}$, hasil $P_{\max }$ per $A$ tidak bisa dikatakan sebagai kuat tekan beton, melainkan hanya dapat disebut sebagai tegangan beton, perlu dikalikan dengan angka konversi untuk menjadikannya menjadi kuat tekan beton. Untuk beton silinder dengan ukuran d 7,5 $\mathrm{cm}$ x $15 \mathrm{~cm}$ perlu dilakukan konversi, yaitu dengan faktor pengali 0,943 .

Tabel 7. Rekapitulasi Hasil Pengujian Kuat Tekan Beton

\begin{tabular}{|c|c|c|c|c|c|c|c|c|c|c|c|c|}
\hline \multirow{3}{*}{$\begin{array}{c}\text { Kode } \\
\text { BU } \\
\text { ACC }\end{array}$} & \multicolumn{12}{|c|}{ Umur Pengujian (hari) } \\
\hline & \multicolumn{3}{|c|}{3} & \multicolumn{3}{|c|}{7} & \multicolumn{3}{|c|}{14} & \multicolumn{3}{|c|}{28} \\
\hline & $\begin{array}{c}P_{\max } \\
(\mathrm{kN})\end{array}$ & $\begin{array}{c}\text { Tegangan } \\
\text { Beton } \\
(\mathrm{MPa})\end{array}$ & $\begin{array}{l}\text { Kuat } \\
\text { Tekan } \\
(\mathrm{MPa})\end{array}$ & $\begin{array}{c}P_{\max } \\
(\mathrm{kN})\end{array}$ & $\begin{array}{c}\text { Tegangan } \\
\text { Beton } \\
(\mathrm{MPa})\end{array}$ & $\begin{array}{c}\text { Kuat } \\
\text { Tekan } \\
(\mathrm{MPa})\end{array}$ & $\begin{array}{c}P_{\max } \\
(\mathrm{kN})\end{array}$ & $\begin{array}{c}\text { Tegangan } \\
\text { Beton } \\
(\mathrm{MPa})\end{array}$ & $\begin{array}{l}\text { Kuat } \\
\text { Tekan } \\
\left(\mathrm{MPa}_{\mathrm{a}}\right)\end{array}$ & $\begin{array}{c}P_{\max } \\
(\mathrm{kN})\end{array}$ & $\begin{array}{c}\text { Tegangan } \\
\text { Beton } \\
(\mathrm{MPa})\end{array}$ & $\begin{array}{l}\text { Kuat } \\
\text { Tekan } \\
\text { (Mpa) }\end{array}$ \\
\hline$\%$ & 92.22 & 20.87 & 19.68 & 137.60 & 31.15 & 29.37 & 161.60 & 36.58 & 34.49 & 190.04 & 43.02 & 40.57 \\
\hline $0,4 \%$ & 94.69 & 21.43 & 20.21 & 145.64 & 32.97 & 31.09 & 179.54 & 40.64 & 38.32 & 201.88 & 45.70 & 43.09 \\
\hline $1,2 \%$ & 98.67 & 22.33 & 21.06 & 171.74 & 38.87 & 36.66 & 190.56 & 43.13 & 40.67 & 211.56 & 47.89 & 45.16 \\
\hline $2 \%$ & 99.11 & 22.43 & 21.15 & 175.23 & 39.66 & 37.40 & 210.47 & 47.64 & 44.92 & 230.11 & 52.09 & 49.12 \\
\hline
\end{tabular}

Berdasarkan tabel 7. dapat diketahui kuat tekan sebenarnya dari masing-masing benda uji. Dari tabel tersebut dapat dilihat bahwa semakin tinggi kadar accelerator yang diberikan dan semakin lama umur pengujian beton, maka kuat tekan betonnya akan semakin tinggi.

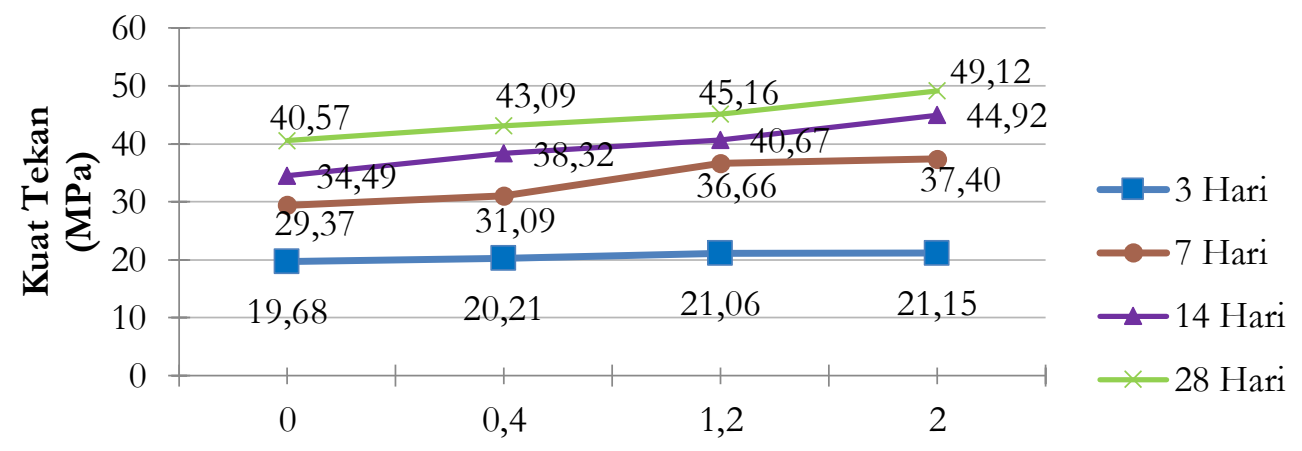

Kadar Accelerator

$(\%)$

Gambar 4. Grafik Kuat Tekan Beton SCC dengan Kadar Accelerator pada Masing-Masing Variasi Hari

Dari tabel 7. dapat dibuat grafik kuat tekan seperti yang terdapat pada gambar 4. sesuai dengan SNI- 03-64682000 definisi dari beton mutu tinggi (bigh strength concrete) ialah campuran beton yang memiliki kuat tekan lebih besar sama dengan 41,4 MPa. Pada gambar 4. terlihat jelas bahwa semakin banyak kadar accelerator maka semakin besar kuat tekan yang didapat.

Perbandingan Hasil Pengujian Kuat Tekan dan Umur Pengujian Beton 


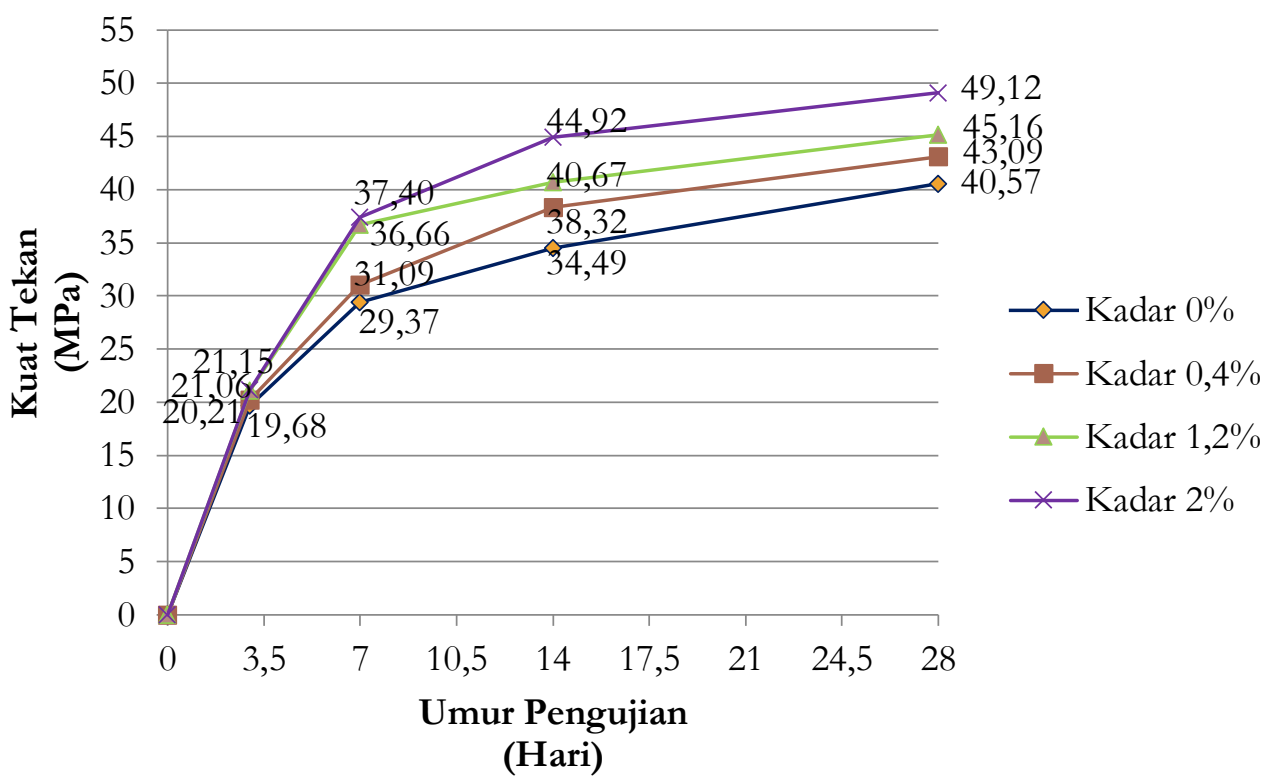

Gambar 5. Grafik Hasil Pengujian Kuat Tekan dengan Umur Pengujian Beton

Dari gambar 5. dapat dilihat bahwa penambahan kadar maksimum terjadi pada penambahan kadar accelerator $2 \%$ dengan nilai kuat tekan sebesar 49,12 MPa pada umur 28 hari. Tetapi kadar accelerator $2 \%$ tidak dapat mencapai beton Self Compacting Concrete (SCC). Untuk kadar accelerator 1,2\% juga tidak dapat mencapai beton Self Compacting Concrete (SCC). Hanya kadar accelerator 0,4\% yang dapat mencapai beton Self Compacting Concrete (SCC). Sehingga dapat disimpulkan bahwa persentase maksimum kadar accelerator yang dapat digunakan agar dapat mencapai High Strength Self Compacting Concrete (HSSCC) adalah 0,4\%. Dengan nilai kuat tekan sebesar 43,09 MPa, memenuhi standar minimum kuat tekan beton mutu tinggi yang disyaratkan SNI-03-6468-2000.

\section{KESIMPULAN}

Setelah melakukan pengujian terhadap parameter beton memadat mandiri dan kuat tekan beton mutu tinggi dengan penambahan kadar superplasticizer $0,8 \%$ dan variasi kadar accelerator pada benda uji silinder berukuran d 7,5 $\mathrm{cm} \times 15$ cm umur 3, 7, 14, dan 28 hari dapat diambil kesimpulan sebagai berikut:

1. Berdasarkan hasil uji SCC pada beton segar, penggantian semen dengan kadar accelerator sebesar $0,4 \%$ memberikan hasil yang baik karena mampu memenuhi hampir seluruh parameter SCC dengan standar EFNARC.

2. Berdasarkan hasil pengujian kuat tekan beton yang menggunakan superplasticizer $0,8 \%$ dan variasi penambahan accelerator menunjukkan bahwa semakin tinggi penambahan kadar accelerator dan semakin lama umur beton, maka kuat tekan beton yang dihasilkan semakin tinggi.

3. Persentase maksimum kadar accelerator yang dapat digunakan agar dapat mencapai High Strength Self Compacting Concrete (HSSCC) adalah 0,4\%. Dengan nilai kuat tekan sebesar 43,09 MPa, memenuhi standar minimum kuat tekan beton mutu tinggi yang disyaratkan SNI-03-6468-2000.

\section{REFERENSI}

Anonim. (2002). ASTM C.40. Standard Test Method for Organic Impurities in Fine Aggregates for Concrete. Association of Standard Testing Materials (ASTM). United States.

Anonim. (2002). ASTM C.117. Standard Test Method for Materias Finer than 75-um(No.200) Sieve in Mineral Aggregates by $W$ ashing. Association of Standard Testing Materials. (ASTM). United States.

Anonim. (2002). ASTM C-128. Standart Test Method for Materials, Specific Gravity dan Absorbtion of Fine Aggregate.

Association of Standard Testing Materials. (ASTM). United States. 
Anonim. (2002). ASTM C-131-01. Standart Test Method for Resistance to Degradation of Small-Size Coarse Aggregate by Abrasion and Impact in the Los Angeles Machine. Association of Standard Testing Materials. (ASTM). United States.

Badan Standarisasi Nasional. (2000). Tata Cara Perencanaan Campuran Tinggi dengan Semen Portland dengan Abu Terbang (SNI 03-6468-2000). Badan Standardisasi Nasional. Jakarta Pusat.

Departemen Pekerjaan Umum dan Tenaga Listrik. (1971). "Peraturan Beton Bertulang Indonesia (PBI-1971). Bandung.

Departemen Pekerjaan Umum. (1989). Metode Pengujian Kuat Tekan Beton (SK SNI M-14-1989-F). Yayasan LPMB. Bandung.

Departemen Pekerjaan Umum. (1990). Tata Cara Pembuatan Rencana Campuran Beton Normal (SK SNI T-15-199003). Yayasan LPMB. Bandung.

Departemen Pekerjaan Umum, Pusat Jalan dan Jembatan. (2011). Cara Uji Kuat Tekan Beton dengan Benda Uji Silinder (SNI 1974: 2011). Standar Nasional Indonesia. Jakarta.

EFNARC. (2002). Specification and Guidelines for Self-Compacting Concrete.UK

Fadillah, S.T. (2017). Kajian Pengaruh Variasi Penambahan Bahan Accelerator Terbadap Parameter Beton Memadat Mandiri Dengan Kuat Tekan Beton Mutu Tinggi. Skripsi pada Program Studi Teknik Sipil Fakultas Teknik Universitas Sebelas Maret Surakarta: tidak diterbitkan.

Hartono, et.al (2007). Pertimbangan pada Perbaikan dan Perkuatan Struktur Bangun Pasca Gempa, Seminar HAKI. Jakarta.

Neville, A.M. (1995). Properties of Concrete, Fourth and Final Edition. Longman Group Limited: England.

Parrot, L. J. (1998). A Literature Review of High Strength Concrete Properties, Wexham Springs: British Cement Association (BCA).

Standar Industri Indonesia (SII) 0052-80 (1980). "Mutu dan Cara Uji Agregat". Departemen Perindustrian Republik Indonesia.

Tjokrodimulyo, K. (2007). Teknologi Beton. Biro Penerbit Jurusan Teknik: Yogyakarta.

Tjaronge, M.Wihardi, et.al. (2006). Pecahan Marmer sebagai Pengganti Parsial Agregat Kasar Self Compacting Concrete (SCC), Jurnal Desain \& Konstruksi Vol.5, Jurusan Teknik Sipil Unhas. 